\title{
Biologics in the treatment of psoriasis and emerging new therapies in the pipeline
}

\author{
This article was published in the following Dove Press journal: \\ Psoriasis: Targets and Therapy \\ 16 June 2012 \\ Number of times this article has been viewed
}

\author{
Lauren L Levy* \\ Shayna M Solomon* \\ Jason J Emer \\ Department of Dermatology, \\ Mount Sinai School of Medicine, \\ New York, NY, USA \\ *Both authors contributed equally \\ to this work and represent co-first \\ authorship
}

Correspondence: Jason J Emer Mount Sinai School of Medicine, Department of Dermatology, 5 East 98th Street, 5th Floor, New York, NY 10029, USA

$\mathrm{Tel}+\mathrm{I} 2126599530$

$\mathrm{Fax}+\mathrm{I} 2123487434$

Email Jason.emermd@gmail.com

\begin{abstract}
Elucidation of the immunopathogenesis of psoriasis has led to the discovery of novel biologic agents for the treatment of moderate-to-severe plaque psoriasis. There are currently five biologic agents approved by the US Food and Drug Administration for psoriasis which have proven to be quite efficacious in clinical trials and in post-marketing and clinical experience. As more details are uncovered about the immunologic pathways involved in initiation and maintenance of this disease, there will be an increasing development and marketing of novel therapeutics. It is crucial to understand the immunopathogenesis of psoriasis and the mechanisms of these novel agents in order to to treat the psoriatic population effectively and mitigate disease burden. This article reviews the currently approved biologics for the treatment of psoriasis, with emphasis on efficacy and safety. There are countless therapies currently in the research pipeline, with mechanisms ranging from receptor antagonism to signal transduction pathway inhibition. The initial trials and future studies involving these new agents are also reviewed. As therapeutics escalate through the research pipeline, the management and treatment of psoriasis will likely become more manageable for practitioners and patients.
\end{abstract}

Keywords: psoriasis, treatment, biologics

\section{Introduction}

Psoriasis is a chronic immunologically mediated multisystemic disease affecting approximately 125 million people worldwide. ${ }^{1}$ The signs and symptoms vary drastically from one patient to another. While patients with limited local disease may respond to topical intervention, others having a large affected body surface area and/or joint disease will require systemic treatment for management. Increased knowledge of the immunopathogenesis of psoriasis has led to improvement in existing treatment options and novel targeted therapies. The development of treatments that modulate key molecules in the pathogenesis of psoriasis has revolutionized management of the disease, leading to a research focus on the development of these novel biologic agents. ${ }^{2}$ This article will review currently approved biologic agents as well as promising options in the pipeline for the treatment of psoriasis. It is crucial that providers understand the mechanisms of action of these systemic agents to maximize treatment outcomes.

\section{Immune system and psoriasis}

Psoriasis is a disease of T cell dysregulation. ${ }^{3,4}$ As early as the 1970 s, T cells were hypothesized to induce and perpetuate psoriatic disease. ${ }^{5-8}$ However, more recently, the pathogenesis of psoriasis has been further elucidated, implicating a more complex 
immune cascade and identifying new disease modulators as potential therapeutic targets ${ }^{9,10}$ (Figure 1).

The cell-mediated adaptive immune response is primarily responsible for initiation and maintenance of the disease. ${ }^{11,12}$ While T-helper (Th1) cytokines, ie, interferon-gamma (IFN- $\gamma$ ), tumor necrosis factor- $\alpha$ (TNF- $\alpha$ ), interleukin-2 (IL-2), and IL-12 have long been implicated in the pathogenesis of psoriasis, new research demonstrates the role of Th17 cells in the evolution of the disease. ${ }^{13,14}$ Th17 cells are stimulated by IL-23 and produce many recently identified proinflammatory cytokines, such as IL-17 and IL-22, leading to the recruitment of neutrophils and dysregulation of keratinocytes seen in psoriasis. ${ }^{15}$ IFN- $\gamma$ functions synergistically with IL-17 to produce IL-6 and IL-8, which also act to recruit inflammatory cells such as neutrophils. Other studies have shown that Th1 cells can induce the production of Th17 cells through the production of chemokine (C-C motif) ligand-20, a cytokine chemoattractant for dendritic cells, lymphocytes such as Th17 cells, and neutrophils. ${ }^{16}$ Further understanding of the role of IL-12 in the production of Th1 cells and its complex interaction within the IL-23/Th17 axis will provide a rationale for unique targeted therapies.

TNF- $\alpha$, produced by both activated dendritic cells and T cells, including Th1, Th17, and Th22, is often elevated in inflammatory conditions including psoriasis, as evidenced by increased levels found in the serum and blister fluid of patients with the disease. ${ }^{17}$ Gene studies have also demonstrated that when TNF- $\alpha$ interacts with IL-17, there is a corresponding increase in gene expression that correlates with the degree of inflammation. ${ }^{18}$ Among the newest factors identified in the pathogenesis of psoriasis are IL-22 and
IL-20, which share a common receptor complex (IL-22R1). ${ }^{19}$ IL-22 effects keratinocyte terminal differentiation, resulting in epidermal hyperplasia and acanthosis, the well known psoriatic phenotype. ${ }^{20,21}$ IL-20, produced by keratinocytes, further perpetuates epidermal hyperplasia, through activation of IL-22R1. ${ }^{22}$ Thus, the IL-22R1 receptor appears to be a novel driver of inflammation through positive autoregulatory loops. In clinical studies, elevated serum levels of IL-20 and IL-22 in psoriatic patients correlate with the Psoriasis Assessment Severity Index (PASI). ${ }^{23-25}$ These newly discovered cytokines serve as potential targets for the treatment of psoriasis (Table 1).

\section{Evaluating efficacy of treatment}

Quantifying the severity of psoriasis is important in order to select an appropriate treatment modality and to assess the treatment response subsequently. Clinical trials utilize the PASI to measure improvement of cutaneous lesions objectively; however, this complex system is not practical in busy daily clinical practice. ${ }^{26}$ PASI is used in clinical trials because it allows the researcher to score the three major features of psoriasis objectively, ie, redness (erythema), scaling, and thickness (induration), with consideration of the extent of involvement in each body region. A general standard for evaluating superior treatment efficacy is a PASI 75 , a $75 \%$ improvement from a baseline PASI, and is often considered the primary endpoint of most landmark biologic studies. ${ }^{27}$ However, with newer agents having more targeted mechanisms and increasing clinical efficacy compared with previous landmark studies, it is not uncommon to find a PASI 90 or PASI 100 reported in the literature. Other scales used in
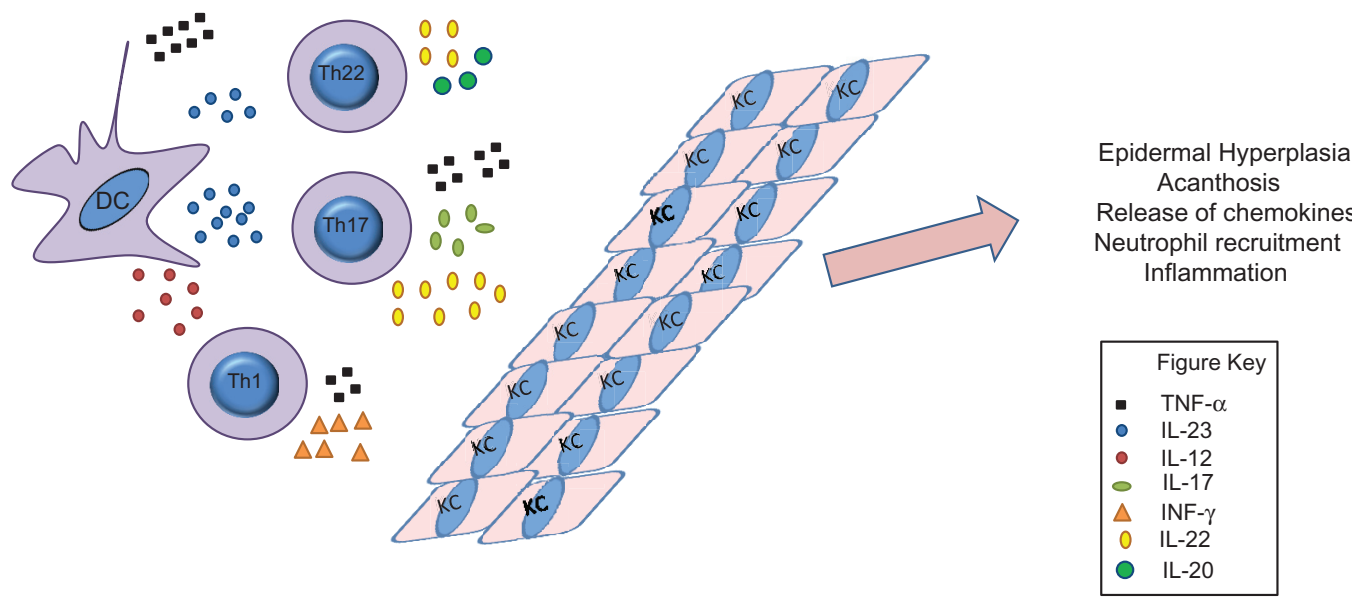

Figure I The immune pathogenesis of psoriasis involving key inflammatory cells and mediators.

Abbreviations: DC, dendritic cell; Th, T-helper; KC, keratinocyte; TNF, tumor necrosis factor; IL, interleukin; INF, interferon. 
Table I Immunology of psoriasis and immunotherapeutic targets

\begin{tabular}{|c|c|c|c|}
\hline Target & Mechanism of action & Therapy & Drug \\
\hline ThI cells & Releases inflammatory cytokines & T cell inhibition & Alefacept \\
\hline \multirow{3}{*}{ TNF- $\alpha$} & Proinflammatory cytokine released by & Inhibition of TNF- $\alpha$ & Etanercept \\
\hline & activated DCs and T cells & & Infliximab \\
\hline & & & Adalimumab \\
\hline \multirow[t]{2}{*}{ IL-12 } & Promotes differentiation of ThI cells & Antibody to IL-I2/23 & Ustekinumab \\
\hline & & & Briakinumab \\
\hline \multirow[t]{2}{*}{ IL-23 } & Released by activated DCs & Antibody to IL-I2/23 & Ustekinumab \\
\hline & Promotes differentiation of ThI 7 cells & & Briakinumab \\
\hline \multirow[t]{3}{*}{ IL-I7 } & Produced by ThI7 cells & Antibodies to IL-I7 and its receptor & Secukinumab \\
\hline & Upregulates inflammatory chemokines & & LY-243982I \\
\hline & & & AMG-827 \\
\hline \multirow[t]{3}{*}{ IL-22 } & Produced by Th22 cells & Antibody to IL-22 & ILV-094 \\
\hline & Induces epidermal hyperplasia and acanthosis & & \\
\hline & Prevents epidermal terminal differentiation & & \\
\hline \multirow[t]{4}{*}{ JAK } & Initiates the transduction of key inflammatory cytokines & JAK inhibitors & CP-690, 550 \\
\hline & Induces ThI7 differentiation & & VX-509 \\
\hline & & & R348 \\
\hline & & & INCB-018424 \\
\hline P38 kinase & Activates cytokine production & P38 kinase inhibitor & BMS-582949 \\
\hline PKC & T cell activation & PKC inhibitor & AEB07I \\
\hline Calcineurin & T cell activation & Calcineurin inhibition & Voclosporin \\
\hline Adenosine & Promotes production of inflammatory cells and cytokines & Adenosine $\mathrm{A} 3$ receptor inhibitor & CF-IOI \\
\hline PDE 4 & Signaling pathway produces inflammatory cytokines & PDE 4 inhibitor & Apremilast \\
\hline
\end{tabular}

Abbreviations: TNF, tumor necrosis factor; DC, dendritic cell; IL, interleukin; JAK, janus kinase; PKC, protein kinase C; PDE, phosphodiesterase; Th, T-helper.

the evaluation of treatment success include the Physicians Global Assessment (PGA), a measurement of overall disease severity at any given time point for evaluation in a study, and the Dermatology Life Quality Index (DLQI), a questionnaire used for routine clinical assessment of improvement in quality of life following treatment. ${ }^{28,29}$

\section{Conventional therapies}

Approximately $80 \%$ of the psoriatic population has mildto-moderate disease (localized cutaneous manifestations; body surface area $\leq 10 \%$ ) of which the majority can be successfully managed with topical agents such as corticosteroids, vitamin D3 analogs, vitamin A derivatives, emollients, keratolytics, and/or coal tar. ${ }^{30,31}$ Moderate-to-severe disease with more widespread cutaneous manifestations (body surface area $>10 \%$ ) and/or nail or joint disease may require phototherapy (ultraviolet $\mathrm{B}$ or ultraviolet $\mathrm{A}$ radiation) with psoralen, known as photochemotherapy, or systemic agents. ${ }^{32}$ Conventional systemic therapies such as MTX, CSA and acitretin can be used in the long term, but often have limitations due to more severe side effects (organ toxicity, skin cancer), lack of sustainable efficacy, and inconvenient administration schedules. ${ }^{33,34}$ Nonetheless, such agents remain a necessity in our therapeutic armamentarium primarily due to their established drug profiles and cost-effectiveness. Furthermore, an unfortunate truth in the US is that most insurance companies require failure of systemic therapy and/or phototherapy prior to approval of a biologic treatment.

\section{Targeted biologic therapy}

Elucidation of the immunologic circuits in the pathogenesis of psoriasis has encouraged the development of novel targeted systemic treatment options known as "biologics". By targeting specific pathways in the immunopathogenesis of psoriasis, progression of the disease can be interrupted, resulting in both cutaneous and systemic disease clearance. In some instances, disease clearance may be complete (eg, PASI 100) and long-standing.

There are currently five biologic agents approved by the US Food and Drug Administration for psoriasis, alefacept (Amevive $^{\circledR}$, Biogen Inc, Cambridge, MA), etanercept $\left(\right.$ Enbrel $^{\circledR}$, Amgen, Seattle, WA), infliximab (Remicade ${ }^{\circledR}$, Janssen Biotech Inc, Horsham, PA), adalimumab (Humira ${ }^{\circledR}$, Abbott Laboratories, North Chicago, IL), and ustekinumab $\left(\right.$ Stelara $^{\circledR}$, Janssen Biotech Inc) ${ }^{35-39}$ (Table 2). Newer more targeted agents are in development and in clinical trials.

Another immunosuppressant inhibiting lymphocyte activation and cell migration out of blood vessels into tissues, efalizumab (Raptiva ${ }^{\circledR}$, Genentech, South San 
Table 2 Biologics approved by the US Food and Drug Administration for psoriasis

\begin{tabular}{|c|c|c|c|c|c|c|}
\hline Drug & $\begin{array}{l}\text { Year } \\
\text { approved }\end{array}$ & Mechanism of action & Dosing for psoriasis & $\begin{array}{l}\text { Other FDA- } \\
\text { approved } \\
\text { indications }\end{array}$ & Cost/unit & $\begin{array}{l}\text { Cost for first year } \\
\text { of treatment }\end{array}$ \\
\hline Alefacept ${ }^{35}$ & 2003 & T cell inhibition & $\begin{array}{l}\text { Weekly } 15 \mathrm{mg} \\
\text { IM injection for } 12 \text { weeks }\end{array}$ & Ps & $\begin{array}{l}\$ 562.75 / 15 \mathrm{mg} \\
\text { vial }\end{array}$ & $\$ 27,577^{40}$ \\
\hline Etanercept $\mathrm{t}^{36}$ & 2004 & $\begin{array}{l}\text { Fusion protein combined } \\
\text { with human }|g G| \text { to } \\
\text { antagonize TNF- } \alpha\end{array}$ & $\begin{array}{l}\text { SC injection of } \\
50 \mathrm{mg} \text { BIW for } 12 \text { weeks, } \\
\text { followed by } 50 \mathrm{mg} \text { weekly }\end{array}$ & $\begin{array}{l}\text { JIA, RA, PsA, } \\
\text { AS, Ps }\end{array}$ & $\begin{array}{l}\$ 90.10 / 25 \mathrm{mg} \\
\text { syringe } \\
\$ 180.19 / 50 \mathrm{mg} \\
\text { syringe }\end{array}$ & $\$ 26,862^{40}$ \\
\hline Infliximab ${ }^{37}$ & 2006 & $\begin{array}{l}\text { Chimeric monoclonal } \\
\text { antibody to TNF- } \alpha\end{array}$ & $\begin{array}{l}\text { IV infusion of } 5 \mathrm{mg} / \mathrm{kg} \\
\text { at } 0,2 \text {, and } 6 \text { weeks, } \\
\text { followed by } 5 \mathrm{mg} / \mathrm{kg} \\
\text { every } 8 \text { weeks }\end{array}$ & $\begin{array}{l}\text { RA, PsA, CD, } \\
\text { Ps, UC, AS }\end{array}$ & $\begin{array}{l}\$ 408.35 / 100 \mathrm{mg} \\
\text { vial }\end{array}$ & $\$ 23,639^{40}$ \\
\hline Adalimumab ${ }^{38}$ & 2008 & $\begin{array}{l}\text { Recombinant human } \\
\text { monoclonal antibody to } \\
\text { TNF- } \alpha\end{array}$ & $\begin{array}{l}80 \mathrm{mg} \text { SC injection, } \\
\text { followed by } 40 \mathrm{mg} \text { EOW } \\
\text { beginning one week } \\
\text { after initial dose }\end{array}$ & $\begin{array}{l}\text { RA, JIA, PsA, } \\
\text { Ps, AS, CD }\end{array}$ & $\begin{array}{l}\$ 345.45 / 40 \mathrm{mg} \\
\text { syringe }\end{array}$ & $\$ 23,538^{40}$ \\
\hline Ustekinumab ${ }^{39}$ & 2009 & $\begin{array}{l}\text { Monoclonal antibody to } \\
\text { common p } 40 \text { subunit of } \\
\text { IL-I } 2 / 23\end{array}$ & $\begin{array}{l}\mathrm{SC} \text { injection of } 45 \mathrm{mg} \\
\text { (weight } \leq 100 \mathrm{~kg} \text { ) or } \\
90 \mathrm{mg} \text { (weight }>100 \mathrm{~kg} \text { ) } \\
\text { at weeks } 0 \text { and } 4, \text { followed } \\
\text { by } 45 \mathrm{mg} \text { or } 90 \mathrm{mg} \\
\text { every } 12 \text { weeks }\end{array}$ & Ps & $\begin{array}{l}\$ 3475.33 / 45 \mathrm{mg} \\
\text { vial }\end{array}$ & $\$ 33,576^{41}$ \\
\hline
\end{tabular}

Abbreviations: Ps, psoriasis; FDA, Food and Drug Administration; mg, milligram; TNF, tumor necrosis factor; SC, subcutaneous; BIW, biweekly; JIA, juvenile idiopathic arthritis; RA, rheumatoid arthritis; PsA, psoriatic arthritis; AS, ankylosing spondylitis; IM, intramuscular; IV, intravenous; kg, kilogram; CD, Crohn's disease; UC, ulcerative colitis; EOW, every other week; IL, interleukin.

Francisco, CA), was taken off the market in 2009 when four cases of progressive multifocal leukoencephalopathy (John Cunningham virus brain infection) were reported in plaque psoriasis patients. ${ }^{42,43}$ Other similar biologics, golimumab and certolizumab pegol, have efficacy in psoriasis, but are indicated for other conditions, such as psoriatic arthritis, rheumatoid arthritis, ankylosing spondylitis, and Crohn's disease. The following is a discussion of the pivotal clinical trials, the efficacy and safety of the currently approved biologics for psoriasis, in addition to the drugs under clinical investigation or development.

\section{Alefacept}

Alefacept is a humanized, recombinant, dimeric, fusion protein of lymphocyte function-associated antigen and human immunoglobulin G1 (IgG1), that binds to cluster of differentiation-2(CD2), a cell adhesion molecule on memory $\mathrm{T}$ cells, to inhibit lymphocyte activation in psoriatic plaques..$^{44,45}$ Alefacept is administered as a $15 \mathrm{mg}$ intramuscular injection weekly for 12 weeks.

\section{Efficacy}

Alefacept was the first biologic agent approved for the treatment of psoriasis after trials demonstrated a statistically significant improvement in clearance rates versus placebo.
PASI 75 and 50 were achieved by $33 \%$ and $57 \%$, of patients, respectively, who received alefacept $15 \mathrm{mg}$ intramuscularly at weekly intervals for 12 weeks. ${ }^{46} \mathrm{~A}$ maximum improvement from baseline was noted 6 weeks following the last treatment, indicating an interesting post-dosing effect. A single course of alefacept was durable, because a PASI 50 was maintained for an average of 7 months after treatment cessation. ${ }^{47}$

Additional treatment courses provided clinical improvement without increasing toxicity for those who did not obtain an adequate response after weekly $15 \mathrm{mg}$ intramuscular injections for 12 weeks (a single course). ${ }^{48}$ If multiple treatment courses are anticipated, it is generally recommended to have a gap of 12 weeks for clinical observation between courses. In one randomized trial, up to five courses of intramuscular alefacept were well tolerated. ${ }^{49}$ Preliminary data suggest that courses of therapy longer than 12 weeks may enhance efficacy as well, although further research is still necessary. ${ }^{46}$

\section{Safety}

Alefacept is currently the only approved $\mathrm{T}$ cell modulator for the treatment of psoriasis. Efalizumab was the only other agent in a similar class, but was removed from the market in 2009 after it was associated with demyelinating central nervous disease as described above. ${ }^{50}$ Alefacept has not been 
associated with demyelinating disease and is generally well tolerated.

Alefacept induces dose-dependent reductions in $\mathrm{T}$ lymphocytes, therefore reduction in the $\mathrm{CD} 4^{+} \mathrm{T}$ cell count is a potential safety concern. $\mathrm{CD}^{+} \mathrm{T}$ cell counts must be monitored before initiation of therapy and every 2 weeks throughout the 12-week treatment course. Therapy should be halted if the $\mathrm{CD}^{+} \mathrm{T}$ cell count falls below 250 cells $/ \mu \mathrm{L}$ and discontinued completely if the count remains below this threshold for one month. ${ }^{35}$

In clinical trials, chills within the first 24 hours of the initial treatment dose were reported in $10 \%$ of patients versus $1 \%$ of those treated with placebo. ${ }^{47}$ Elevations in liver enzymes have been reported in the drug-treated groups, although there has been no report of clinical significance in these elevations. ${ }^{46,47}$ The observational AWARE (Amevive Wisdom Acquired from Real-World Evidence) trial is a multicenter Phase IV Canadian registry of psoriasis patients treated with alefacept which has further substantiated previous conclusions that alefacept is both efficacious and safe, with few serious adverse events reported and no requirement to discontinue the drug for persistently low $\mathrm{CD} 4^{+} \mathrm{T}$ cell counts. ${ }^{51}$

\section{TNF- $\alpha$ inhibitors}

\section{Etanercept}

Etanercept is a recombinant, human $\mathrm{TNF}-\alpha$ receptor protein linked to the fragment crystallizable region of human IgG1, which inhibits both soluble and membrane-bound TNF- $\alpha .^{36,52}$

Etanercept has shown extensive long-term benefit in patients with moderate-to-severe psoriasis, with clinical trials reporting PASI 75 scores up to $49 \%$. A randomized Phase III trial demonstrated superior efficacy of three dosing regimens, with a PASI 75 (after 12 weeks of treatment) achieved in $4 \%, 14 \%, 34 \%$, and $49 \%$ of patients in the placebo, lowdose, medium-dose, and high-dose groups, respectively. ${ }^{52-54}$ The CRYSTEL (Clinical Randomized Year-Long Study Assessing the Safety and Efficacy of Etanercept in Psoriasis) study, a 54-week open-label investigation of patients with moderate-to-severe plaque psoriasis, demonstrated that both continuous and intermittent etanercept treatment regimens improved PASI scores and quality of life. ${ }^{55,56}$ Patients in the continuous group received $25 \mathrm{mg}$ of subcutaneous etanercept twice weekly for 54 weeks, while the intermittent group received etanercept $50 \mathrm{mg}$ subcutaneously twice weekly for a maximum of 12 weeks or until a PGA $\leq 2$ (mild or better) was reached. When patients experienced treatment relapse (PGA $\geq 3$ ), etanercept was resumed at $25 \mathrm{mg}$ subcutaneously twice weekly until an adequate response $(\mathrm{PGA} \leq 2)$ was again achieved. Both the continuous and intermittent treatment groups had significant improvement in PASI scores from baseline at week 54 (68\% and 59\%, respectively) indicating that those who restart treatment can still achieve a clinical response.

The sustainability of clinical efficacy has also been established, utilizing PGA and DLQI scores over a period of up to 4 years. ${ }^{57}$ At 48 months, $75.9 \%$ of patients enrolled in one of the two major Phase II trials who received subcutaneous doses of either $25 \mathrm{mg}$ twice weekly, $50 \mathrm{mg}$ weekly, or $50 \mathrm{mg}$ twice weekly maintained a DLQI response of greater than five-point improvement from baseline and 27.8\% maintained a PGA response of clear to almost clear. There were no rates of tuberculosis or lymphoma reported during the study period, and serious adverse events and infections occurred rarely, at a rate of 0.8 events per 100 patient-years and 0.9 events per 100 patient-years, respectively. Thus, the authors concluded that etanercept has long-term benefits and that dose-adjusted rates of adverse events and infections were similar to those in patients receiving placebo.

\section{Infliximab}

Infliximab, an intravenously administered chimeric IgG1 antibody made from both human and murine sequences, neutralizes TNF- $\alpha$ by binding to both the soluble and transmembrane forms. ${ }^{58}$

In a multicenter, double-blind, placebo-controlled Phase II trial, 249 patients with chronic plaque psoriasis who had failed previous treatments were enrolled to receive infliximab. ${ }^{59}$ Patients received placebo or infliximab $3 \mathrm{mg} / \mathrm{kg}$ or $5 \mathrm{mg} / \mathrm{kg}$ intravenously at 0,2 , and 6 weeks. At week 10 , PASI 75 was achieved by $6 \%, 72 \%$, and $88 \%$ of patients in the placebo, $3 \mathrm{mg} / \mathrm{kg}$, and $5 \mathrm{mg} / \mathrm{kg}$ groups, respectively. Rapid improvement occurred soon after the first infusion, with a clinical response evident as early as week 2 of treatment.

The Phase III EXPRESS (European Infliximab for Psoriasis [Remicade] Efficacy and Safety Study) evaluated the efficacy and safety of infliximab for induction and maintenance therapy or induction therapy followed by multiple regimens of maintenance therapy. ${ }^{60,61}$ Significant results from the initial EXPRESS I trial in which the treatment group received $5 \mathrm{mg} / \mathrm{kg}$ intravenous induction at 0,2 , and 6 weeks followed by maintenance therapy every 8 weeks for 46 weeks showed that $61 \%$ and $45 \%$ of treated patients achieved PASI 75 and PASI 90, respectively, at 50 weeks. Nail psoriasis was also shown to improve significantly in the treatment group. ${ }^{60}$ 
The EXPRESS II trial evaluated the efficacy of continuous versus intermittent maintenance therapy following infliximab induction using both the $3 \mathrm{mg} / \mathrm{kg}$ and $5 \mathrm{mg} / \mathrm{kg}$ dosing regimens. Greater durability of the treatment response was achieved with continuous maintenance therapy. There was a dose-dependent response, with more patients achieving a PASI 75 in the $5 \mathrm{mg} / \mathrm{kg}$ versus the $3 \mathrm{mg} / \mathrm{kg}$ treatment group (75.5\% versus $70.3 \%$ ) compared with the placebo response of $1.9 \%{ }^{61}$

Neutralizing human antichimeric antibodies have been reported to occur in approximately $16 \%$ of patients treated with infliximab. ${ }^{62}$ These are neutralizing antibodies against the murine portion of infliximab and are thought to be responsible for the loss of sustainable treatment efficacy seen in patients treated long-term with infliximab. In contrast, antibodies to etanercept occur less often (approximately 3\%) and are thought to be non-neutralizing. ${ }^{63}$ Patients producing antibodies may experience decreased treatment efficacy with the cause being currently undefined. The presence of these antibodies is not only associated with a reduction in response to infliximab, but is also associated with the development of infusion reactions. ${ }^{64,65}$ The combination of infliximab with low-dose methotrexate can decrease human antichimeric antibody formation and result in increased overall efficacy, decreased chance of loss of treatment efficacy, and decreased rates of infusion reactions. ${ }^{66}$

\section{Adalimumab}

Adalimumab, the first fully human IgG1 monoclonal antibody to TNF- $\alpha$, inhibits binding of the TNF- $\alpha$ molecule to its receptor. ${ }^{38}$ Adalimumab is administered $40 \mathrm{mg}$ subcutaneously every other week after the initial $80 \mathrm{mg}$ subcutaneous loading dose.

A landmark randomized trial compared adalimumab administered by subcutaneous injection (40 mg every other week or $40 \mathrm{mg}$ weekly) versus placebo in the treatment of psoriasis and found that after 2 weeks, more patients treated with adalimumab every other week or weekly achieved at least a $75 \%$ improvement ( $53 \%$ and $80 \%$, respectively) versus $4 \%$ with placebo. ${ }^{67}$ In an open-label extension of the study, improvements were sustained for 60 weeks.

In the milestone Phase III REVEAL (The Randomized controlled EValuation of adalimumab Every other week in moderate to severe psoriasis trial) trial, over 1000 patients were randomized to receive adalimumab $40 \mathrm{mg}$ subcutaneously every other week (after the initial $80 \mathrm{mg}$ subcutaneous loading dose) or placebo for 15 weeks. ${ }^{68}$ At week 16, 71\% versus $7 \%$ achieved PASI 75 in the treatment group and placebo groups, respectively. Patients in the treatment group, who had achieved at least a PASI 75 at week 16, received open-label adalimumab from weeks 17 to 31 . Patients with a PASI 75 response after 33 weeks of continuous therapy were rerandomized to either adalimumab or placebo in order to evaluate loss of adequate response (defined as a PASI score that was less than a 50\% reduction relative to the week 0 baseline score and at least a 6-point increase in PASI score from week 33). The percentage of patients who lost an adequate response was significantly greater for those receiving placebo than for those receiving treatment ( $28 \%$ versus $5 \%$ ).

In a recently published open-label extension of the REVEAL trial, patients received adalimumab for a total of 3 years. ${ }^{69}$ Those who initially sustained PASI 75 during REVEAL maintained their improvement after both 100 and 160 weeks of continuous therapy, and a PASI 75 was achieved by $83 \%$ and $76 \%$ of patients, respectively, with no difference in the safety profile from the original trial. Adalimumab was also demonstrated to be an effective treatment for Japanese patients with psoriasis, with rapid response rates (as early as week 4 ) and PASI 75 achieved by $62.8 \%$ versus $4.3 \%$ of patients when compared with placebo, as evidenced by a recent trial. ${ }^{70}$

Superiority of adalimumab to methotrexate was demonstrated in CHAMPION (the Comparative Study of Humira vs Methotrexate vs Placebo in Psoriasis Patients), where 271 patients were randomized to receive either one of these drugs or placebo. ${ }^{71}$ PASI 75 was achieved by $79.6 \%$ of patients in the adalimumab group, $35.5 \%$ in the methotrexate group, and $18.9 \%$ in the placebo group.

Since this antibody is completely humanized, it has been suggested that antibodies against the drug are less likely. Studies have substantiated this hypothesis as only $8 \%$ of patients have evidence of antibody formation. However, the presence of these antibodies may explain a resultant loss of clinical response in some patients after long-term use. ${ }^{72,73}$

\section{Safety}

TNF- $\alpha$ antagonists have been utilized in the treatment of rheumatoid arthritis and inflammatory bowel disease for over 10 years, so safety data has been demonstrated and justified by use of these agents in diseases other than psoriasis. However, data from the psoriasis trials confirm the established drug profiles. Major organ toxicities associated with conventional systemic therapies are not observed with TNF- $\alpha$ antagonists, although hepatitis has been reported with the use of infliximab. Infections, including severe opportunistic infections and 
tuberculosis, are a noted risk, and all three agents have a black box warning required by the Food and Drug Administration concerning the development of serious infections, including tuberculosis and disseminated fungal diseases, such as coccidioides and histoplasmosis. ${ }^{74,75}$ Opportunistic infections have been reported, but many of the patients were treated concomitantly with other immunosuppressive agents, which is typical of treatment for inflammatory bowel disease or rheumatoid arthritis, but far less common in the treatment of psoriasis, possibly limiting the potential for infection in this population. ${ }^{76-78}$ The Food and Drug Administration recently requested that the etanercept boxed warning and prescribing information be updated to include legionella, listeria, and blastomycosis as potential infectious risks. ${ }^{79}$

Treatment may slightly increase the risk of melanocytic and nonmelanocytic skin cancers, including squamous cell carcinoma, basal cell carcinoma, and cutaneous $\mathrm{T}$ cell lymphoma ${ }^{80,81} \mathrm{~A}$ comprehensive observational study reported that patients receiving TNF- $\alpha$ inhibitors for rheumatoid arthritis had a 1.5 odds ratio for nonmelanocytic skin cancers and a trend towards increased risk of melanoma (odds ratio 2.3) ${ }^{82}$ The increased risk of lymphoma and other solid organ cancers is less clear. Studies have produced conflicting reports, have been underpowered to assess the risk of rare events, and have been tainted by the fact that patients with psoriatic disease are at an intrinsic increased risk of developing lymphoma. ${ }^{83-85}$

Other reported events include development or worsening of both central and peripheral demyelinating diseases, druginduced lupus-like syndromes, and worsening of congestive heart failure. Despite these safety concerns, meta-analyses of published trials conclude that the benefit of successful treatment is greater than the risk of serious events or toxicity ${ }^{86}$

\section{Ustekinumab}

Ustekinumab is a novel, fully humanized IgG1 monoclonal antibody specific for the common p 40 subunit of both IL-12 and IL-23 which prevents interaction with their receptor and inhibits $T$ cell differentiation. Administered as a subcutaneous injection, ustekinumab is dosed by weight at $45 \mathrm{mg}$ (weight $\leq 100 \mathrm{~kg}$ ) or $90 \mathrm{mg}$ (weight $>100 \mathrm{~kg}$ ), and is administered every 12 weeks after the initial two doses spaced four weeks apart. ${ }^{39}$

\section{Efficacy}

Initial Phase I data revealed that a single dose was well tolerated and resulted in a significant clinical response. ${ }^{87}$ Four dosing regimens were evaluated in a double-blind, placebo-controlled Phase II trial and concluded that each therapeutic regimen had efficacy over placebo, with a striking clinical response at 12 weeks and improvement in quality of life as early as 2 weeks. ${ }^{88}$ The major Phase III trials comparing ustekinumab with either placebo in PHOENIX (Phase 3, Multicenter, Randomized, Double-blind, Placebocontrolled Trial Evaluating the Efficacy and Safety of CNTO 1275 in the Treatment of Subjects with moderate to Severe Plaque-type Psoriasis followed by Long-term extension) I/II or etanercept in ACCEPT (Active Comparator CNTO1275/ Enbrel Psoriasis Trial) has confirmed superior safety and efficacy.

The PHOENIX trials assessed both short-term and long-term efficacy and safety in approximately 2000 patients. The studies consisted of three phases, ie, random assignment, crossover at week 12 , and rerandomization. In rerandomization, responders received either placebo or maintenance of active treatment (PHOENIX I) and the partial responders received drug treatment every 8 weeks (dose intensification) or continued treatment every 12 weeks (PHOENIX II). ${ }^{89,90}$ A PASI 75 response was achieved by up to $67.1 \%$ of patients at week 12 in the higher-dosed group during PHOENIX I. The maximum response was achieved by week 24 for both dosing groups. A PASI 75 response was better maintained to at least one year in those receiving maintenance ustekinumab than in those withdrawn from treatment at week $40{ }^{89}$ Patients reported that quality of life was significantly improved when compared with placebo, indicated by a separate analysis of this trial. ${ }^{91}$ PHOENIX II further established the effect of ustekinumab, when patients achieving a PASI 75 at week 28 and continued on maintenance treatment until week 52 sustained their clinical response. At week 28, partial responders (defined as those achieving a PASI score between 50 and 75) were randomly assigned to continue 12-weekly dosing or to escalate to 8-weekly dosing. Interestingly, more frequent dosing did not enhance response rates at one year in patients receiving $45 \mathrm{mg}$, but did enhance improvement rates in those receiving $90 \mathrm{mg}$. Independent predictors of a partial response included treatment with the lower dose, higher body weight, failure to respond to at least one biologic agent, longer duration of psoriasis, and a history of psoriatic arthritis. Notably, ustekinumab antibodies were present in $13 \%$ of partial responders, compared with only $2.0 \%$ of complete responders, defined as those achieving a PASI $75 .^{90}$

The pivotal ACCEPT trial demonstrated superior efficacy of ustekinumab (45 mg or $90 \mathrm{mg}$ ) over high-dose etanercept (50 mg subcutaneous twice weekly). At week 12, a PASI 75 was achieved in $73.8 \%, 67.5 \%$, and $56.8 \%$ of patients in the ustekinumab $90 \mathrm{mg}$, ustekinumab $45 \mathrm{mg}$, and etanercept 
groups, respectively. Additionally, no significant safety differences were found between the groups. ${ }^{92}$

\section{Safety}

The long-term effects of ustekinumab remain unknown, and much information will stem from post-marketing surveillance and additional long-term studies. Cumulative safety experience was analyzed through the pooling of safety data from the four Phase II and III psoriasis trials gathered over 3 years of treatment. Rates of serious infection during the placebo-controlled periods were similar between placebo (1.70) and ustekinumab $90 \mathrm{mg}$ (1.97) groups, yet lower in the ustekinumab $45 \mathrm{mg}$ group (0.49). ${ }^{93}$ The rates of nonmelanoma skin cancer and other malignancies were consistent with the expected incidence in the general US population based on the Surveillance, Epidemiology, and End Results (SEER) database. ${ }^{94}$

A major concern is the disproportionate number of major adverse cardiac events seen in the first 12 weeks of the Phase II trial. ${ }^{88}$ Ultimately, it was determined that a high proportion of patients recruited into the trials had significant cardiovascular risk factors, such as obesity, smoking, high blood pressure, and diabetes. ${ }^{95-97}$ However, significant concern about this issue prompted a retraction of the US Food and Drug Administration approval for briakinumab (another humanized monoclonal antibody to the p40 subunit of IL-12 and IL-23), and clinical trials were stopped in the treatment of psoriasis.

A meta-analysis of randomized, placebo-controlled, double-blind, monotherapy studies evaluated cardiovascular outcomes for the anti-IL-12/23 agents (ustekinumab and briakinumab) and anti-TNF- $\alpha$ agents (adalimumab, etanercept, and infliximab). The primary outcome was a major adverse cardiac event during the placebo-controlled portion of the study. ${ }^{98}$ There were more major adverse cardiac events reported in patients who received active treatment with anti-IL-12/23 inhibitors than in the placebo group (10/3179 patients versus 0/1474 patients). These results lack statistical significance, suggesting that an increase in major adverse cardiac events during the early weeks of treatment may be due to an inherent disease risk in the psoriatic patient population.

\section{Monitoring of patients receiving biologic therapy}

Given that there are adverse events associated with biologic therapy, it is necessary to prescreen patients prior to initiation and to continue monitoring patients during and after treatment
(Table 3). Various agencies, such as the Food and Drug Administration and Centers for Disease Control, in addition to key consensus statements, have provided recommendations regarding monitoring. ${ }^{99,100}$ Prior to initiation, it is recommended to obtain a complete medical history and physical examination, as well as baseline laboratory values. ${ }^{101}$ All recommendations on monitoring protocol stem from reported adverse events, and differ depending on the mechanism of action of the agent concerned (Table 4).

\section{New drugs in pipeline: from small molecules to receptors}

The list of agents that are under development for psoriasis continues to expand as further understanding of the pathogenesis of the disease is elucidated. Drugs in the research pipeline include oral, injectable, and topical agents that inhibit ILs, IL receptors, or molecules involved in immunologic signaling cascades. Many of these drugs are in Phase II and III trials, while others are just approaching human administration in Phase I trials.

\section{Monoclonal antibodies}

\section{Secukinumab}

Secukinumab (AIN-457, Novartis, Chicago, IL) is a fully humanized IgG monoclonal antibody to IL-17A, an inflammatory mediator implicated in autoimmune diseases, including psoriasis. Phase III trials are currently investigating efficacy in the treatment of moderate to severe psoriasis, psoriatic arthritis, and rheumatoid arthritis. ${ }^{103-105}$ Initial Phase

Table 3 Recommendations for monitoring patients on biological therapy $^{99-102}$

- $\mathrm{CBC}$ and $\mathrm{CMP}$ at baseline and every 3-6 months

- Hepatitis and HIV screen at baseline if risk factors present or if symptoms develop

- LFTs before each infliximab infusion or with signs and symptoms of liver injury

- $\mathrm{CD} 4^{+} \mathrm{T}$ cell count at baseline and every 2 weeks for alefacept

- Full body screen for skin cancer and signs of systemic disease (lymphoma) every 3-6 months

- Standard vaccinations prior to initiation of biologic therapy

- Injected influenza*, pneumococcal, and/or hepatitis vaccination to high-risk individuals prior to initiation of biologic therapy

- Avoidance of live and/or live-attenuated vaccinations while on biological therapy (MMR, nasal spray influenza, varicella, herpes zoster, yellow fever, rabies, BCG, typhoid)

Note: *Inactivated influenza vaccination can be administered for patients already started on biologic agents.

Abbreviations: CBC, complete blood count; CMP, complete metabolic panel; HIV, human immunodeficiency virus; LFT, liver function test; CD4, cluster of differentiation 4; MMR, measles, mumps, and rubella; BCG, bacillus calmette-guerin. 
Table 4 Notable adverse events of biologics approved for psoriasis

\begin{tabular}{|c|c|}
\hline Alefacept ${ }^{35}$ & $\begin{array}{l}\text { - Exacerbation of HIV, hepatitis B and C } \\
\text { - Reduction in CD4+ } \mathrm{T} \text { cell count } \\
\text { - Elevation of LFTs }\end{array}$ \\
\hline TNF- $\alpha$ inhibitors ${ }^{36-38}$ & $\begin{array}{l}\text { - Reactivation of TB } \\
\text { - Opportunistic infections } \\
\text { - Worsening of CHF } \\
\text { - Development or worsening of } \\
\text { - demyelinating diseases } \\
\text { - Increased risk of NMSC, melanoma, and } \\
\text { lymphoma } \\
\text { - Elevation of LFTs }\end{array}$ \\
\hline Ustekinumab 39 & - MACE \\
\hline
\end{tabular}

Abbreviations: HIV, human immunodeficiency virus; LFTs, liver function tests; $\mathrm{TB}$, tuberculosis; $\mathrm{CHF}$, congestive heart failure; NMSC, nonmelanoma skin cancer; MACE, major adverse cardiac events.

II trials and preliminary reports reveal improved PASI scores after a single intravenous administration when compared with placebo, with similar adverse events in the treatment and placebo group. ${ }^{106}$ After monthly subcutaneous administration of $150 \mathrm{mg}$, PASI 75 at 12 weeks was achieved by $81 \%$ of study participants. ${ }^{107}$ Ongoing Phase III trials in patients with psoriasis are studying the long-term safety and efficacy of AIN-457, in addition to dosing regimens (150 mg versus $300 \mathrm{mg}$ subcutaneous versus placebo) for both maintenance and for therapy following relapse..$^{108,109}$

\section{AMG-827}

AMG-827 (Amgen) is a fully humanized antibody that selectively targets the human IL-17 receptor and is currently in Phase II trials for psoriasis and rheumatoid arthritis. ${ }^{10,111}$ Following a single intravenous injection (700 mg), skin biopsies from treated subjects showed variant cytokine gene expression. Studies demonstrated a decrease in genes implicated in psoriasis, especially those associated with epidermal thickness and markers of cellular proliferation. Clinical response was also significant, as seven of eight $(87.5 \%)$ treated patients achieved a PASI 75 or greater at week $6 .{ }^{112}$

\section{LY243982 I}

LY2439821 (Eli Lilly, Indianapolis, IA) is a humanized IgG4 monoclonal antibody that neutralizes IL-17 with high specificity, and was found to be efficacious for patients with rheumatoid arthritis when compared with placebo in a randomized Phase I proof-of-concept study. ${ }^{113}$ A Phase II study evaluating the efficacy of subcutaneous administration at various doses (10-150 mg) for a total of six doses $(0,2,4,8,12$, and 16 weeks) for patients with moderate-to-severe plaque psoriasis is still ongoing. ${ }^{114}$
A Phase III trial evaluating efficacy and safety following an induction dosing period ( $80 \mathrm{mg}$ subcutaneous twice at week 0 ) with a subsequent randomized maintenance dose period and long-term extension follow-up period began recruiting patients in November 2011 with an estimated primary completion date of April 2014. ${ }^{115}$

\section{Fezakinumab}

Fezakinumab (ILV-094, Pfizer Inc, New York, NY) is a monoclonal antibody targeting IL-22, a cytokine that has shown to affect keratinocytes by inducing hyperplasia and acanthosis. ${ }^{21}$ Phase II trials have been completed for rheumatoid arthritis and a Phase I trial investigating both subcutaneous and intravenous administration at 2-week intervals has been completed without published results. ${ }^{116,117}$

\section{Oral anti-inflammatory agents}

\section{Apremilast}

Apremilast (CC-10004, Celgene, Summit, NJ) is a phosphodiesterase-4 inhibitor shown to decrease TNF- $\alpha$ production. Apremilast reduces epidermal thickness and reduced expression of TNF- $\alpha$ in a murine model of psoriasis. ${ }^{118} \mathrm{~A}$ larger Phase IIb trial randomized 352 patients with moderate-to-severe plaque psoriasis to receive either apremilast (10 mg, $20 \mathrm{mg}$, and $30 \mathrm{mg}$ ) orally twice daily or placebo. The study showed that $41 \%, 29 \%$, and $11 \%$ of patients in the $30 \mathrm{mg} 20 \mathrm{mg}$, and $10 \mathrm{mg}$ treatment arms, respectively, achieved a PASI 75 at 16 weeks compared with $6 \%$ of placebo-treated patients. ${ }^{119}$ Phase III trials are currently underway evaluating the efficacy of $30 \mathrm{mg}$ twice a day with subsequent retreatment at the same dose following discontinuation and relapse (loss of PASI 50) as well for psoriatic arthritis. ${ }^{120,121}$

\section{Voclosporin}

Voclosporin (ISA-247, Isotechnika Pharma, Edmonton, Canada) is similar to cyclosporine in that it is also a calcineurin inhibitor; however, this new drug differs by having an amino acid modification resulting in increased binding to calcineurin and faster elimination of metabolites. In turn, it appears the overall effect is a greater physiologic response with fewer adverse events, especially in regards to renal toxicity. ${ }^{122,123}$ Initial Phase II studies showed that orally administered voclosporin was superior to placebo after 12 weeks of treatment, with a PASI 75 achieved by $66.7 \%$ of drug-treated patients versus none of the placebo-treated patients. ${ }^{122,124}$ Trials demonstrated that plasma voclosporin concentrations 
correlated with the clinical response, suggesting that drug efficacy may be accomplished by monitoring blood levels, which is a limitation with the other calcineurin inhibitors. Quality of life measures, including the DLQI and the Psoriasis Disability Index, a questionnaire investigating the level of harm resulting from psoriasis, were shown to improve following treatment. ${ }^{125}$

Unlike other calcineurin inhibitors, voclosporin does not result in permanent renal toxicity or increase blood pressure and lipid levels following treatment; however, creatinine levels increase at higher treatment doses. ESSENCE (the European and Canadian pivotal Phase 3 psoriasis trial) was the first study to compare the efficacy of cyclosporine and voclosporin directly where patients were randomized to receive voclosporin $0.4 \mathrm{mg} / \mathrm{kg}$ orally twice daily, cyclosporine $1.5 \mathrm{mg} / \mathrm{kg}$ orally twice daily, or placebo. ${ }^{126}$ At 12 weeks, 35\% of patients achieved a score of clear or almost clear on static PGA score compared with $6 \%$ of those on placebo. Additionally, a PASI 75 was achieved by $43 \%$ and $26 \%$ of voclosporin-treated patients at 12 and 60 weeks, respectively. Voclosporin had significant improvements when compared with cyclosporine in rates of hypertension and hyperlipidemia, and had fewer reported adverse events.

\section{CF-IOI}

CF-101 (Can-Fite, Waltham, MA) is an adenosine A3 receptor inhibitor that also inhibits the production of inflammatory cytokines, such as TNF- $\alpha$ and autoreactive T cells, and also induces apoptosis of inflammatory cells. ${ }^{127}$ Prior to trials in psoriasis, Phase II trials for rheumatoid arthritis and keratoconjunctivitis sicca established the drug to be safe and well tolerated. Phase II trials have demonstrated improvement in mean PASI scores from baseline after 12 weeks of $2 \mathrm{mg}$ twice daily oral dosing, with $35.5 \%$ of subjects achieving PASI 50 and $23.5 \%$ of patients achieving a PGA score of 0 or $1 .{ }^{128}$ Although Phase III trials for psoriasis have not yet been completed, the existing information supports the safety and efficacy of CF-101 in patients with moderate to severe psoriasis. ${ }^{129}$ Currently, Phase III trials for dry eye and Phase II trials for increased intraocular pressure and knee osteoarthritis are ongoing. ${ }^{130-132}$

\section{Sotrastaurin}

Sotrastaurin (AEB-071, Novartis AG, Basel, Switzerland) is an inhibitor of numerous subtypes of protein kinase $C$, which ultimately leads to the prevention of early $\mathrm{T}$ cell activation. ${ }^{133}$ Sotrastaurin inhibits $\mathrm{T}$ cell proliferation in a dose-dependent manner and reduces the production of key cytokines, including IL-17, IFN- $\gamma$, IL-2, and TNF- $\alpha .{ }^{134}$ When treatment groups received 25, 100, 200, or 300 mg orally twice daily a mean reduction in PASI scores was achieved during the initial 2 weeks of treatment. The average decrease of PASI scores over baseline was $69 \%$ for the $300 \mathrm{mg}$ twice daily cohort, which was the highest dosage tested. The majority of patients in this treatment group (66.7\%) achieved a PASI 75. ${ }^{135}$ However, many patients in the treated groups relapsed during the 2-week treatment-free follow-up period and only patients in the highest dose group still showed sustained clinical improvement. The treatment was well tolerated, with the incidence of adverse events being similar in the treatment and placebo groups; however, larger clinical studies are necessary to evaluate the true safety of sotrastaurin in addition to its efficacy. Sotrastaurin is currently in Phase II trials for psoriasis, ulcerative colitis, and renal transplant rejection, in addition to Phase I trials for metastatic uveal melanoma. ${ }^{136-139}$

\section{BMS-582949}

BMS-582949 (Bristol-Myers Squibb, New York, NY) is a p38 kinase inhibitor and is currently in Phase II trials for psoriasis. The p38 membrane-associated protein kinases are a family of serine/threonine protein kinases that play an important role in the cellular response to external stimuli, including stress signals. TNF- $\alpha$ stimulation and production has been linked to signals originating from p38 membraneassociated protein kinases. ${ }^{140}$ Preclinical models have suggested that inhibition of the p38 membrane-associated protein kinase pathway can reduce skin inflammation in animals. ${ }^{141}$ Phase II trials for psoriasis, rheumatoid arthritis, and atherosclerosis have been completed, with no relevant data published in the peer-reviewed journals at the time of writing of this article. ${ }^{142-144}$

\section{Janus kinase inhibitors}

\section{Tofacitinib}

One of the emerging new targets in the treatment of psoriasis is the Janus kinase (JAK) pathway, which is comprised of cytoplasmic tyrosine kinase proteins that phosphorylate and activate the signal transducer and activator of transcription transduction pathway associated with production of Th17 cells. ${ }^{145}$ As a selective inhibitor of JAK3, tofacitinib (CP-690550, Pfizer Inc, New York, NY) suppresses signal transduction of ILs, including IL-2, IL-7, IL-9, IL-15, and IL-21. ${ }^{146}$ 
Results from a Phase II trial which randomized 197 subjects to receive $2 \mathrm{mg}, 5 \mathrm{mg}, 15 \mathrm{mg}$ of oral tofacitinib or placebo twice daily were presented at the annual meeting of the European Academy of Dermatology and Venereology held in October 2010 at Gothenburg, Sweden. A PASI 75 was achieved by $25 \%, 40.8 \%$, and $66.7 \%$ of drug-treated patients compared with $2.0 \%$ of placebo-treated patients. ${ }^{147}$ Although the adverse events in this study were comparable with those reported for other biologic agents, the Phase III trial in rheumatoid arthritis has reported four deaths, none of which have not been linked with tofacitinib. Ongoing Phase III trials are evaluating the safety of tofacitinib in the psoriatic population. ${ }^{148}$ Other selective JAK3 inhibitors are in the initial phases of development for psoriasis and rheumatoid arthritis, although no published data are currently available. ${ }^{149}$

\section{Ruxolitinib}

Ruxolitinib (INCB018424, Incyte Corporation, Wilmington, $\mathrm{DE}$ ) is a topically administered inhibitor of the JAK1 and JAK2 molecule, and was shown to reduce cutaneous edema, lymphocyte infiltration, keratinocyte proliferation, acanthosis, and IL-22 in a murine model of cutaneous inflammation. ${ }^{150}$ The drug is currently in Phase II development for psoriasis, myelofibrosis, acute leukemia, polycythemia vera, and essential thrombocytosis. ${ }^{151-155}$

\section{Conclusion}

Immunomodulators including biologics have changed the therapeutic management of psoriasis, providing physicians with the opportunity to directly target the known key mediators in the pathogenesis of this disease. The demand for novel and improved therapies continues to grow, and can only be met by continued research. New biologic agents will continue to target more specific, smaller molecules involved in the inflammatory cascade to help limit side effects while maximizing efficacy. The previous advances made in biological therapy for the treatment of psoriasis have laid the foundation for drugs in the research pipeline allowing us to focus our treatment considerations dramatically.

\section{Disclosure}

The authors report no conflicts of interest in this work.

\section{References}

1. Gelfand JM, Stern RS, Nijsten T, et al. The prevalence of psoriasis in African Americans: results from a population-based study. J Am Acad Dermatol. 2005;52(1):23-26.

2. Lebwohl M. Psoriasis. Lancet. 2003;361(9364):1197-1204.
3. Gottlieb SL, Gilleaudeau P, Johnson R, et al. Response of psoriasis to a lymphocyte-selective toxin (DAB389IL-2) suggests a primary immune, but not keratinocyte, pathogenic basis. Nat Med. 1995;1(5):442-447.

4. Nickoloff BJ, Turka LA, Mitra RS, Nestle FO. Direct and indirect control of T-cell activation by keratinocytes. J Invest Dermatol. 1995; 105(Suppl 1):25S-29S.

5. Braun-Falco O, Schmoeckel C. The dermal inflammatory reaction in initial psoriatic lesions. Arch Dermatol Res. 1977;258(1):9-16.

6. Baker BS, Swain AF, Valdimarsson H, Fry L. T-cell subpopulations in the blood and skin of patients with psoriasis. Br J Dermatol. 1984;110(1): $37-44$.

7. Ellis CN, Gorsulowsky DC, Hamilton TA, et al. Cyclosporine improves psoriasis in a double-blind study. JAMA. 1986;256(22):3110-3116.

8. Fierlbeck G, Rassner G, Müller C. Psoriasis induced at the injection site of recombinant interferon gamma. Results of immunohistologic investigations. Arch Dermatol. 1990;126(3):351-355.

9. Nograles KE, Krueger JG. Anti-cytokine therapies for psoriasis. Exp Cell Res. 2011;317(9):1293-1300.

10. Bos JD, de Rie MA, Teunissen MB, Piskin G. Psoriasis: dysregulation of innate immunity. Br J Dermatol. 2005;152(6):1098-1107.

11. Valdimarsson H, Baker BS, Jónsdóttir I, Powles A, Fry L. Psoriasis: a T-cell-mediated autoimmune disease induced by streptococcal superantigens? Immunol Today. 1995;16(3):145-149.

12. Nickoloff BJ, Nestle FO. Recent insights into the immunopathogenesis of psoriasis provide new therapeutic opportunities. J Clin Invest. 2004; 113(12):1664-1675.

13. Oppmann B, Lesley R, Blom B, et al. Novel p19 protein engages IL-12p40 to form a cytokine, IL-23, with biological activities similar as well as distinct from IL-12. Immunity. 2000;13(5):715-725.

14. Cornelissen F, van Hamburg JP, Lubberts E. The IL-12/IL-23 axis and its role in Th17 cell development, pathology and plasticity in arthritis. Curr Opin Investig Drugs. 2009;10(5):452-462.

15. Zaba LC, Fuentes-Duculan J, Eungdamrong NJ, et al. Psoriasis is characterized by accumulation of immunostimulatory and Th1/Th17 cell-polarizing myeloid dendritic cells. J Invest Dermatol. 2009;129(1): 79-88.

16. Kryczek I, Bruce AT, Gudjonsson JE, et al. Induction of IL-17+ T cell trafficking and development by IFN-gamma: mechanism and pathological relevance in psoriasis. J Immunol. 2008;181(7):4733-4741.

17. Bonifati C, Carducci M, Cordiali Fei P, et al. Correlated increases of tumour necrosis factor-alpha, interleukin-6 and granulocyte monocytecolony stimulating factor levels in suction blister fluids and sera of psoriatic patients - relationships with disease severity. Clin Exp Dermatol. 1994;19(5):383-387.

18. Chiricozzi A, Guttman-Yassky E, Suárez-Fariñas M, et al. Integrative responses to IL-17 and TNF- $\alpha$ in human keratinocytes account for key inflammatory pathogenic circuits in psoriasis. J Invest Dermatol. 2011; 131(3):677-687.

19. Leng RX, Pan HF, Tao JH, Ye DQ. IL-19, IL-20 and IL-24: potential therapeutic targets for autoimmune diseases. Expert Opin Ther Targets. 2011;15(2):119-126.

20. Sa SM, Valdez PA, Wu J, et al. The effects of IL-20 subfamily cytokines on reconstituted human epidermis suggest potential roles in cutaneous innate defense and pathogenic adaptive immunity in psoriasis. J Immunol. 2007;178(4):2229-2240.

21. Boniface K, Bernard FX, Garcia M, Gurney AL, Lecron JC, Morel F. IL-22 inhibits epidermal differentiation and induces proinflammatory gene expression and migration of human keratinocytes. $J$ Immunol. 2005;174(6):3695-3702.

22. He M, Liang P. IL-24 transgenic mice: in vivo evidence of overlapping functions for IL-20, IL-22, and IL-24 in the epidermis. J Immunol. 2010; 184(4):1793-1798.

23. Coimbra S, Oliveira H, Reis F, et al. Interleukin (IL)-22, IL-17, IL-23, IL-8, vascular endothelial growth factor and tumour necrosis factor- $\alpha$ levels in patients with psoriasis before, during and after psoralen-ultraviolet A and narrowband ultraviolet B therapy. Br J Dermatol. 2010;163(6):1282-1290. 
24. Kagami S, Rizzo HL, Lee JJ, Koguchi Y, Blauvelt A. Circulating Th17, Th22, and Th1 cells are increased in psoriasis. J Invest Dermatol. 2010;130(5):1373-1383.

25. Lo YH, Torii K, Saito C, Furuhashi T, Maeda A, Morita A. Serum IL-22 correlates with psoriatic severity and serum IL-6 correlates with susceptibility to phototherapy. J Dermatol Sci. 2010;58(3): 225-227.

26. Spuls PI, Lecluse LL, Poulsen ML, Bos JD, Stern RS, Nijsten T. How good are clinical severity and outcome measures for psoriasis?: quantitative evaluation in a systematic review. J Invest Dermatol. 2010; 130(4):933-943.

27. Naldi L, SvenssonA, DiepgenT, etal; for European Dermato-Epidemiology Network. Randomized clinical trials for psoriasis 1977-2000: the EDEN survey. J Invest Dermatol. 2003;120(5):738-741.

28. Langley RG, Ellis CN. Evaluating psoriasis with Psoriasis Area and Severity Index, Psoriasis Global Assessment, and Lattice System Physician's Global Assessment. J Am Acad Dermatol. 2004;51(4): 563-569.

29. Finlay AY, Khan GK. Dermatology Life Quality Index (DLQI) - a simple practical measure for routine clinical use. Clin Exp Dermatol. 1994;19(3):210-216.

30. Pèrez A, Chen TC, Turner A, et al. Efficacy and safety of topical calcitriol (1,25 dihydroxyvitamin D3) for the treatment of psoriasis. Br J Dermatol. 1996;134(2):238-246.

31. Mason AR, Mason J, Cork M, Dooley G, Edwards G. Topical treatments for chronic plaque psoriasis. Cochrane Database Syst Rev. 2009;2: CD005028.

32. Menter A, Korman NJ, Elmets CA, et al. Guidelines of care for the management of psoriasis and psoriatic arthritis: section 4. Guidelines of care for the management and treatment of psoriasis with traditional systemic agents. J Am Acad Dermatol. 2009;61(3):451-485.

33. Kalb RE, Strober B, Weinstein G, Lebwohl M. Methotrexate and psoriasis: 2009 National Psoriasis Foundation Consensus Conference. $J$ Am Acad Dermatol. 2009;60(5):824-837.

34. Rosmarin DM, Lebwohl M, Elewski BE, Gottlieb AB; for National Psoriasis Foundation. Cyclosporine and psoriasis: 2008 National Psoriasis Foundation Consensus Conference. J Am Acad Dermatol. 2010; 62(5):838-853.

35. Amevive [package insert]. Cambridge, MA: Biogen Inc; December 2011.

36. Enbrel [package insert]. Thousand Oaks, CA: Amgen; December 2011.

37. Remicade [package insert]. Horsham, PA: Janssen Biotech Inc; October 2011.

38. Humira [package insert]. North Chicago, IL: Abbott Laboratories; December 2011

39. Stelara [package insert]. Horsham, PA: Janssen Biotech Inc; August 2011.

40. Beyer V, Wolverton SE. Recent trends in systemic psoriasis treatment costs. Arch Dermatol. 2010;146(1):46-54.

41. Schafer JA, Kjesbo NK, Gleason PP. Formulary review of 2 new biologic agents: tocilizumab for rheumatoid arthritis and ustekinumab for plaque psoriasis. J Manag Care Pharm. 2010;16(6):402-416.

42. Raptiva [package insert] South San Francisco, CA: Genentech Inc; 2006.

43. Major EO. Progressive multifocal leukoencephalopathy in patients on immunomodulatory therapies. Annu Rev Med. 2010;61:35-47.

44. Chamian F, Lin SL, Lee E, et al. Alefacept (anti-CD2) causes a selective reduction in circulating effector memory $\mathrm{T}$ cells $(\mathrm{Tem})$ and relative preservation of central memory $\mathrm{T}$ cells $(\mathrm{Tcm})$ in psoriasis. $J$ Transl Med. 2007;5:27.

45. Majeau GR, Meier W, Jimmo B, Kioussis D, Hochman PS. Mechanism of lymphocyte function-associated molecule 3-Ig fusion proteins inhibition of $\mathrm{T}$ cell responses. Structure/function analysis in vitro and in human CD2 transgenic mice. J Immunol. 1994;152(6): $2753-2767$.
46. Lebwohl M, Christophers E, Langley R, Ortonne JP, Roberts J, Griffiths CE; for Alefacept Clinical Study Group. An international, randomized, double-blind, placebo-controlled Phase 3 trial of intramuscular alefacept in patients with chronic plaque psoriasis. Arch Dermatol. 2003;139(6):719-727.

47. Krueger GG, Papp KA, Stough DB, Loven KH, Gulliver WP, Ellis CN; for Alefacept Clinical Study Group. A randomized, double-blind, placebo-controlled Phase III study evaluating efficacy and tolerability of 2 courses of alefacept in patients with chronic plaque psoriasis. J Am Acad Dermatol. 2002;47(6):821-833.

48. Gordon KB, Langley RG. Remittive effects of intramuscular alefacept in psoriasis. J Drugs Dermatol. 2003;2(6):624-628.

49. Roberts JL, Ortonne JP, Tan JK, Jaracz E, Frankel E; for Alefacept Clinical Study Group. The safety profile and sustained remission associated with response to multiple courses of intramuscular alefacept for treatment of chronic plaque psoriasis. J Am Acad Dermatol. 2010; 62(6):968-978

50. Pugashetti R, Koo J. Efalizumab discontinuation: a practical strategy. J Dermatolog Treat. 2009;20(3):132-136.

51. Wexler D, Searles G, Landells I, et al. Update on alefacept safety. J Cutan Med Surg. 2009;13 Suppl 3:S139-S147.

52. Leonardi CL, Powers JL, Matheson RT, et al; for Etanercept Psoriasis Study Group. Etanercept as monotherapy in patients with psoriasis. N Engl J Med. 2003;349(21):2014-2022.

53. Papp KA, Tyring S, Lahfa M, et al; for Etanercept Psoriasis Study Group. A global Phase III randomized controlled trial of etanercept in psoriasis: safety, efficacy, and effect of dose reduction. Br J Dermatol. 2005;152(6):1304-1312.

54. Tyring S, Gottlieb A, Papp K, et al. Etanercept and clinical outcomes, fatigue, and depression in psoriasis: double-blind placebo-controlled randomised Phase III trial. Lancet. 2006;367(9504):29-35.

55. Ortonne JP, Griffiths C, Daudén E, et al. Efficacy and safety of continuous versus paused etanercept treatment in patients with moderate-to-severe psoriasis over 54 weeks: the CRYSTEL study. Exp Rev Dermatol. 2008;3:657-665.

56. Daudén E, Griffiths CE, Ortonne JP, et al. Improvements in patientreported outcomes in moderate-to-severe psoriasis patients receiving continuous or paused etanercept treatment over 54 weeks: the CRYSTEL study. J Eur Acad Dermatol Venereol. 2009;23(12):1374-1382.

57. Papp KA, Poulin Y, Bissonnette R, et al. Assessment of the long-term safety and effectiveness of etanercept for the treatment of psoriasis in an adult population. $J$ Am Acad Dermatol. 2012;66(2):e33-e45.

58. Scallon BJ, Moore MA, Trinh H, Knight DM, Ghrayeb J. Chimeric anti-TNF-alpha monoclonal antibody cA2 binds recombinant transmembrane TNF-alpha and activates immune effector functions. Cytokine. 1995;7(3):251-259.

59. Gottlieb AB, Evans R, Li S, et al. Infliximab induction therapy for patients with severe plaque-type psoriasis: a randomized, double-blind, placebo-controlled trial. J Am Acad Dermatol. 2004;51(4):534-542.

60. Reich K, Nestle FO, Papp K, et al; for EXPRESS study investigators. Infliximab induction and maintenance therapy for moderateto-severe psoriasis: a Phase III, multicentre, double-blind trial. Lancet. 2005;366(9494):1367-1374.

61. Menter A, Feldman SR, Weinstein GD, et al. A randomized comparison of continuous vs intermittent infliximab maintenance regimens over 1 year in the treatment of moderate-to-severe plaque psoriasis. $J \mathrm{Am}$ Acad Dermatol. 2007;56(1):31, e1-e15.

62. Menter A, Gottlieb A, Feldman SR, et al. Guidelines of care for the management of psoriasis and psoriatic arthritis: Section 1. Overview of psoriasis and guidelines of care for the treatment of psoriasis withbiologics. J Am Acad Dermatol. 2008;58(5):826-850.

63. Rozin AP. Infliximab efficiency and failure. Ann Rheum Dis. 2004;63(6): 751-752.

64. Wolbink GJ, Vis M, Lems W, et al. Development of antiinfliximab antibodies and relationship to clinical response in patients with rheumatoid arthritis. Arthritis Rheum. 2006;54(3):711-715. 
65. Lebwohl M. New developments in the treatment of psoriasis. Arch Dermatol. 2002;138(5):686-688.

66. Maini RN, Breedveld FC, Kalden JR, et al. Therapeutic efficacy of multiple intravenous infusions of anti-tumor necrosis factor alpha monoclonal antibody combined with low-dose weekly methotrexate in rheumatoid arthritis. Arthritis Rheum. 1998;41(9):1552-1563.

67. Gordon KB, Langley RG, Leonardi C, et al. Clinical response to adalimumab treatment in patients with moderate to severe psoriasis: double-blind, randomized controlled trial and open-label extension study. J Am Acad Dermatol. 2006;55(4):598-606.

68. Menter A, Tyring SK, Gordon K, et al. Adalimumab therapy for moderate to severe psoriasis: A randomized, controlled Phase III trial. J Am Acad Dermatol. 2008;58(1):106-115.

69. Gordon K, Papp K, Poulin Y, Gu Y, Rozzo S, Sasso EH. Long-term efficacy and safety of adalimumab in patients with moderate to severe psoriasis treated continuously over 3 years: results from an open-label extension study for patients from REVEAL. $J$ Am Acad Dermatol. 2012;66(2):241-251.

70. Asahina A, Nakagawa H, Etoh T, Ohtsuki M; for Adalimumab M04-688 Study Group. Adalimumab in Japanese patients with moderate to severe chronic plaque psoriasis: efficacy and safety results from a Phase II/III randomized controlled study. J Dermatol. 2010;37(4): 299-310.

71. Saurat JH, Stingl G, Dubertret L, et al; for CHAMPION Study Investigators. Efficacy and safety results from the randomized controlled comparative study of adalimumab vs methotrexate vs placebo in patients with psoriasis (CHAMPION). Br J Dermatol. 2008; 158(3):558-566.

72. Croom KF, McCormack PL. Adalimumab: in plaque psoriasis. Am J Clin Dermatol. 2009;10(1):43-50.

73. Lecluse LL, Driessen RJ, Spuls PI, et al. Extent and clinical consequences of antibody formation against adalimumab in patients with plaque psoriasis. Arch Dermatol. 2010;146(2):127-132.

74. Keane J, Gershon S, Wise RP, et al. Tuberculosis associated with infliximab, a tumor necrosis factor alpha-neutralizing agent. $N$ Engl J Med. 2001;345(15):1098-1104.

75. Ellerin T, Rubin RH, Weinblatt ME. Infections and anti-tumor necrosis factor alpha therapy. Arthritis Rheum. 2003;48(11):3013-3022.

76. Kamili QA, Menter A. Atypical presentation of histoplasmosis in a patient with psoriasis and psoriatic arthritis on infliximab therapy. J Drugs Dermatol. 2010;9(1):57-60.

77. Slifman NR, Gershon SK, Lee JH, Edwards ET, Braun MM. Listeria monocytogenes infection as a complication of treatment with tumor necrosis factor alpha-neutralizing agents. Arthritis Rheum. 2003;48(2): 319-324.

78. Haroon N, Inman RD. Infectious complications of biological therapy. Curr Opin Rheumatol. 2009;21(4):397-403.

79. United States Food and Drug Administration. FDA Drug Safety Communication: Drug labels for the tumor necrosis factor-alpha $(\mathrm{TNF} \alpha)$ blockers now include warnings about infection with Legionella and Listeria bacteria. September 7, 2011. Available at: http://www.fda. gov/Drugs/DrugSafety/ucm270849.htm. Accessed April 9, 2012.

80. Smith KJ, Skelton HG. Rapid onset of cutaneous squamous cell carcinoma in patients with rheumatoid arthritis after starting tumor necrosis factor alpha receptor IgG1-Fc fusion complex therapy. $J \mathrm{Am}$ Acad Dermatol. 2001;45(6):953-956.

81. Adams AE, Zwicker J, Curiel C, et al. Aggressive cutaneous T-cell lymphomas after TNF alpha blockade. J Am Acad Dermatol. 2004;51(4): 660-662.

82. Wolfe F, Michaud K. Biologic treatment of rheumatoid arthritis and the risk of malignancy: analyses from a large US observational study. Arthritis Rheum. 2007;56(9):2886-2895.

83. Geborek P, Bladström A, Turesson C, et al. Tumour necrosis factor blockers do not increase overall tumour risk in patients with rheumatoid arthritis, but may be associated with an increased risk of lymphomas. Ann Rheum Dis. 2005;64(5):699-703.
84. Bongartz T, Sutton AJ, Sweeting MJ, Buchan I, Matteson EL, Montori V. Anti-TNF antibody therapy in rheumatoid arthritis and the risk of serious infections and malignancies: systematic review and metaanalysis of rare harmful effects in randomized controlled trials. JAMA. 2006;295(19):2275-2285.

85. Gelfand JM, Shin DB, Neimann AL, Wang X, Margolis DJ, Troxel AB. The risk of lymphoma in patients with psoriasis. J Invest Dermatol. 2006;126(10):2194-2201.

86. Langley RG, Strober BE, Gu Y, Rozzo SJ, Okun MM. Benefit-risk assessment of tumour necrosis factor antagonists in the treatment of psoriasis. Br J Dermatol. 2010;162(6):1349-1358.

87. Gottlieb AB, Cooper KD, McCormick TS, et al. A Phase 1, doubleblind, placebo-controlled study evaluating single subcutaneous administrations of a human interleukin-12/23 monoclonal antibody in subjects with plaque psoriasis. Curr Med Res Opin. 2007;23(5):1081-1092.

88. Krueger GG, Langley RG, Leonardi C, et al; for CNTO 1275 Psoriasis Study Group. A human interleukin-12/23 monoclonal antibody for the treatment of psoriasis. $N$ Engl J Med. 2007;356(6):580-592.

89. Leonardi CL, Kimball AB, Papp KA, et al; for PHOENIX 1study investigators. Efficacy and safety of ustekinumab, a human interleukin12/23 monoclonal antibody, in patients with psoriasis: 76-week results from a randomised, double-blind, placebo-controlled trial (PHOENIX 1). Lancet. 2008;371(9625):1665-1674.

90. Papp KA, Langley RG, Lebwohl M, et al; for PHOENIX 2 study investigators. Efficacy and safety of ustekinumab, a human interleukin12/23 monoclonal antibody, in patients with psoriasis: 52-week results from a randomised, double-blind, placebo-controlled trial (PHOENIX 2). Lancet. 2008;371(9625):1675-1684.

91. Lebwohl M, Papp K, Han C, et al. Ustekinumab improves health-related quality of life in patients with moderate-to-severe psoriasis: results from the PHOENIX 1 trial. Br J Dermatol. 2010;162(1):137-146.

92. Griffiths CE, Strober BE, van de Kerkhof P, et al; for ACCEPT Study Group. Comparison of ustekinumab and etanercept for moderateto-severe psoriasis. N Engl J Med. 2010;362(2):118-128.

93. Gordon KB, Papp KA, Langley RG, et al. Long-term safety experience of ustekinumab in patients with moderate to severe psoriasis (Part II of II): Results from analyses of infections and malignancy from pooled phase II and III clinical trials. J Am Acad Dermatol. 2012;66: $742-751$.

94. Reich K, Leonardi C, Griffiths CEM, et al. Update on the cumulative safety experience of ustekinumab: results from the ustekinumab psoriasis clinical development program with up to 4 years of follow-up. Presented at the 22nd World Congress of Dermatology, May 24-29, 2011, Seoul, Korea.

95. Reich K, Langley RG, Lebwohl M, et al. Cardiovascular safety of ustekinumab in patients with moderate to severe psoriasis: results of integrated analyses of data from Phase II and III clinical studies. Br J Dermatol. 2011;164(4):862-872.

96. Gelfand JM, Neimann AL, Shin DB, Wang X, Margolis DJ, Troxel AB. Risk of myocardial infarction in patients with psoriasis. JAMA. 2006;296(14):1735-1741.

97. Mehta NN, Azfar RS, Shin DB, Neimann AL, Troxel AB, Gelfand JM. Patients with severe psoriasis are at increased risk of cardiovascular mortality: cohort study using the General Practice Research Database. Eur Heart J. 2010;31(8):1000-1006.

98. Ryan C, Leonardi CL, Krueger JG, et al. Association between biologic therapies for chronic plaque psoriasis and cardiovascular events: a meta-analysis of randomized controlled trials. JAMA. 2011;306(8): 864-871.

99. Centers for Disease Control and Prevention. Tuberculosis associated with blocking agents against tumor necrosis factor-alpha - California, 2002-2003. MMWR Morb Mortal Wkly Rep. 2004;53(30):683-686.

100. Lebwohl M, Bagel J, Gelfand JM, et al. From the Medical Board of the National Psoriasis Foundation: monitoring and vaccinations in patients treated with biologics for psoriasis. J Am Acad Dermatol. 2008;58(1):94-105. 
101. Levine D, Strober BE. The treatment of moderate-to-severe psoriasis: prescreening and monitoring psoriatic patients on biologics. Semin Cutan Med Surg. 2010;29(1):28-34.

102. Emer JJ, Frankel A, Zeichner JA. A practical approach to monitoring patients on biological agents for the treatment of psoriasis. J Clin Aesthet Dermatol. 2010;3(8):20-26.

103. ClinicalTrials.gov. Efficacy and Safety of Intravenous and Subcutaneous Secukinumab in Moderate to Severe Chronic Plaque-type Psoriasis (STATURE).Available at: http://clinicaltrials.gov/ct2/show/ NCT01412944. Accessed April 18, 2012.

104. ClinicalTrials.gov. Efficacy at 24 weeks and long term safety, tolerability and efficacy up to 2 years of secukinumab (AIN457) in patients with active psoriatic arthritis (PsA). Available at: http://clinicaltrials. gov/ct2/show/NCT01392326. Accessed November 21, 2011.

105. ClinicalTrials.gov. Efficacy at 24 weeks and safety, tolerability and long term efficacy up to 1 year of secukinumab (AIN457) in patients with active rheumatoid arthritis (RA) and an inadequate response to anti-tumor necrosis factor $\alpha$ (anti-TNF $\alpha$ ) agents. Available at: http://clinicaltrials. gov/ct2/show/NCT01350804. Accessed November 21, 2011.

106. Hueber W, Patel DD, Dryja T, et al. Effects of AIN457, a fully human antibody to interleukin-17A, on psoriasis, rheumatoid arthritis, and uveitis. Sci Transl Med. 2010;2(52):52ra72.

107. Papp K, Sigurgeirrson B, Abe M, et al. Secukinumab efficacy and safety preliminary results from a Phase II subcutaneous dose-ranging study in the treatment of moderate-to-severe plaque psoriasis. Presented at the 20th Congress of the European Academy of Dermatology and Venereology, October 20-24, 2011, Lisbon, Portugal.

108. ClinicalTrials.gov. Efficacy and safety of subcutaneous secukinumab for moderate to severe chronic plaque-type psoriasis for up to 1 year (ERASURE). Available at: http://clinicaltrials.gov/ct2/show/ NCT01365455. Accessed November 21, 2011.

109. ClinicalTrials.gov. Efficacy and safety of subcutaneous secukinumab (AIN457) for moderate to severe chronic plaque-type psoriasis assessing different doses and dose regimens (SCULPTURE). Available at: http://clinicaltrials.gov/ct2/show/NCT01406938. Accessed November 21, 2011.

110. ClinicalTrials.gov. Study to assess the long-term safety, tolerability, and efficacy of AMG 827 in subjects with psoriasis. Available at: http:// clinicaltrials.gov/ct2/show/NCT01101100. Accessed November 21, 2011.

111. ClinicalTrials.gov. Safety and efficacy of AMG 827 in subjects with RA. Available at: http://clinicaltrials.gov/ct2/show/NCT01059448. Accessed November 21, 2011.

112. Russell CB, Kerkof K, Bigler J, et al. Blockade of the IL-17R with AMG 827 leads to rapid reversal of gene expression and histopathologic abnormalities in human psoriatic skin. J Invest Dermatol. 2010; 130 Suppl 1:S46.

113. Genovese MC, Van den Bosch F, Roberson SA, et al. LY2439821, a humanized anti-interleukin-17 monoclonal antibody, in the treatment of patients with rheumatoid arthritis: A Phase I randomized, doubleblind, placebo-controlled, proof-of-concept study. Arthritis Rheum. 2010;62(4):929-939.

114. ClinicalTrials.gov. A dose-ranging and efficacy study of LY2439821 (an anti-IL-17 antibody) in patients with moderate-to-severe psoriasis. Available at: http://clinicaltrials.gov/ct2/show/NCT01107457. Accessed November 18, 2011.

115. ClinicalTrials.gov. A Phase 3 study in participants with moderate to severe psoriasis (UNCOVER-1). Available at: http://clinicaltrials.gov/ ct2/show/NCT01474512. Accessed November 18, 2011.

116. ClinicalTrials.gov. Study evaluating the safety and tolerability of ILV-094 in subjects with psoriasis. Available at: http://clinicaltrials. gov/ct2/show/NCT00563524. Accessed November 18, 2011.

117. ClinicalTrials.gov. Study to evaluate the safety and efficacy of ILV-094 in subjects with rheumatoid arthritis. Available at: http:// clinicaltrials.gov/ct2/show/NCT00883896. Accessed November 21, 2011 .
118. Schafer PH, Parton A, Gandhi AK, et al. Apremilast, a cAMP phosphodiesterase-4 inhibitor, demonstrates anti-inflammatory activity in vitro and in a model of psoriasis. Br J Pharmacol. 2010;159(4): 842-855.

119. Monthly prescribing reference. Phase $2 \mathrm{~b}$ study of apremilast for treatment of plaque-type psoriasis. December 16, 2009. Available at: http:// www.empr.com/phase-2b-study-of-apremilast-for-treatment-of-plaquetype-psoriasis/article/159730. Accessed November 18, 2011.

120. ClinicalTrials.gov. Study to evaluate safety and effectiveness of oral apremilast (CC-10004) in patients with moderate to severe plaque psoriasis (ESTEEM 1). Available at: http://clinicaltrials.gov/ct2/show/ NCT01194219. Accessed November 21, 2011.

121. ClinicalTrials.gov. Study to evaluate safety and effectiveness of oral apremilast (CC-10004) in patients with moderate to severe plaque psoriasis (ESTEEM 2). Available at: http://clinicaltrials.gov/ct2/show/ NCT01232283. Accessed November 21, 2011.

122. Bissonnette R, Papp K, Poulin Y, et al; for ISA247 Psoriasis Study Group. A randomized, multicenter, double-blind, placebo-controlled Phase 2 trial of ISA247 in patients with chronic plaque psoriasis. J Am Acad Dermatol. 2006;54(3):472-478.

123. Aspeslet L, Freitag D, Trepanier D, et al. ISA(TX)247: a novel calcineurin inhibitor. Transplant Proc. 2001;33(1-2):1048-1051.

124. Papp K, Bissonnette R, Rosoph L, et al. Efficacy of ISA247 in plaque psoriasis: a randomised, multicentre, double-blind, placebo-controlled Phase III study. Lancet. 2008;371(9621):1337-1342.

125. Kunynetz R, Carey W, Thomas R, Toth D, Trafford T, Vender R. Quality of life in plaque psoriasis patients treated with voclosporin: a Canadian Phase III, randomized, multicenter, double-blind, placebocontrolled study. Eur J Dermatol. 2011;21(1):89-94.

126. Voclosporin Psoriasis Clinical Trials. Phase 3 combined European/ Canadian (ESSENCE) trial. Available at: http://www.isotechnika.com/ in_development/clinical_trials/voclosporin. Accessed November 18, 2011.

127. Bar-Yehuda S, Rath-Wolfson L, Del Valle L, et al. Induction of an antiinflammatory effect and prevention of cartilage damage in rat knee osteoarthritis by CF101 treatment. Arthritis Rheum. 2009;60(10): 3061-3071.

128. David M, Akerman L, Ziv M, et al. Treatment of plaque-type psoriasis with oral CF101: data from an exploratory randomized phase 2 clinical trial. J Eur Acad Dermatol Venereol. 2012;26(3):361-367.

129. ClinicalTrials.gov. Trial of CF101 to treat patients with psoriasis. Available at: http://clinicaltrials.gov/ct2/show/NCT01265667. Accessed November 21, 2011.

130. ClinicalTrials.gov. Trial of CF101 to treat patients with dry eye disease. Available at: http://clinicaltrials.gov/ct2/show/NCT01235234. Accessed November 21, 2011.

131. ClinicalTrials.gov. Safety and efficacy of daily CF101 administered orally in subjects with elevated intraocular pressure. Available at: http:// clinicaltrials.gov/ct2/show/NCT01033422. Accessed November 21, 2011.

132. ClinicalTrials.gov. A study of the efficacy and safety of CF101 to patients with osteoarthritis of the knee. Available at: http://clinicaltrials. gov/ct2/show/NCT00837291. Accessed November 21, 2011.

133. Wagner J, von Matt P, Faller B, et al. Structure-activity relationship and pharmacokinetic studies of sotrastaurin (AEB071), a promising novel medicine for prevention of graft rejection and treatment of psoriasis. J Med Chem. 2011;54(17):6028-6039.

134. Matz M, Weber U, Mashreghi MF, et al. Effects of the new immunosuppressive agent AEB071 on human immune cells. Nephrol Dial Transplant. 2010;25(7):2159-2167.

135. Skvara H, Dawid M, Kleyn E, et al. The PKC inhibitor AEB071 may be a therapeutic option for psoriasis. J Clin Invest. 2008;118(9): 3151-3159.

136. ClinicalTrials.gov. A dose finding study of AEB071 assessing Psoriasis Area and Severity Index in patients with plaque psoriasis. Available at: http://clinicaltrials.gov/ct2/show/NCT0885196. Accessed November 21, 2011. 
137. ClinicalTrials.gov. Efficacy, safety and tolerability of AEB071 in patients with active, moderate to severe ulcerative colitis. Available at: http:// clinicaltrials.gov/ct2/show/NCT00572585. Accessed November 21, 2011.

138. ClinicalTrials.gov. Efficacy, safety and tolerability of AEB071 versus cyclosporine in the novo renal transplant recipients. Available at: http:// clinicaltrials.gov/ct2/show/NCT00504543. Accessed November 21, 2011.

139. ClinicalTrials.gov. Safety and efficacy of AEB071 in metastatic uveal melanoma patients. Available at: http://clinicaltrials.gov/ct2/show/ NCT01430416. Accessed November 21, 2011.

140. Norman P. BMS-582949: crystalline form of a p38alpha inhibitor? WO2008079857. Expert Opin Ther Pat. 2009;19(8):1165-1168.

141. Medicherla S, Ma JY, Reddy M, et al. Topical alpha-selective p38 MAP kinase inhibition reduces acute skin inflammation in guinea pig. J Inflamm Res. 2010;3:9-16.

142. ClinicalTrials.gov. A study of BMS-582949 in patients with moderate to severe plaque psoriasis. Available at: http://clinicaltrials.gov/ct2/ show/NCT00399906. Accessed November 21, 2011.

143. ClinicalTrials.gov. PoC in rheumatoid arthritis with methotrexate. Available at: http://clinicaltrials.gov/ct2/show/NCT00605735. Accessed November 21, 2011.

144. ClinicalTrials.gov. Efficacy study of p38 kinase inhibitor to treat patients with atherosclerosis. Available at: http://clinicaltrials.gov/ ct2/show/NCT00570752. Accessed November 21, 2011.

145. Darnell JE Jr, Kerr IM, Stark GR. Jak-STAT pathways and transcriptional activation in response to IFNs and other extracellular signaling proteins. Science. 1994;264(5164):1415-1421.

146. Ghoreschi K, Jesson MI, Li X, et al. Modulation of innate and adaptive immune responses by tofacitinib (CP-690,550). J Immunol. 2011; 186(7):4234-4243.
147. Businesswire. Oral tasocitinib demonstrates statistically significant response by 12 weeks in Phase 2 study of people with moderate to severe plaque psoriasis. October 7, 2010. Available at: http://www.businesswire. com/news/home/20101130006239/en/Oral-Tasocitinib-DemonstratesStatistically-Significant-Response-12. Accessed November 18, 2011.

148. ClinicalTrials.gov. A one-year study to evaluate the efficacy and safety of CP-690,550 for patients with moderate to severe chronic plaque psoriasis. Available at: http://clinicaltrials.gov/ct2/show/NCT01309737. Accessed December 6, 2011.

149. Chang BY, Zhao F, He X, et al. JAK3 inhibition significantly attenuates psoriasiform skin inflammation in CD18 mutant PL/J mice. J Immunol. 2009; 183(3):2183-2192.

150. Fridman JS, Scherle PA, Collins R, et al. Preclinical evaluation of local JAK1 and JAK2 inhibition in cutaneous inflammation. J Invest Dermatol. 2011;131(9):1838-1844.

151. Incyte Coorporation. Product pipeline. Available at http://www. incytedrugs.com/drugproductpipeline.html. Accessed December 6, 2011.

152. ClinicalTrials.gov. A study of INCB018424 phosphate cream when applied to patients with plaque psoriasis. Available at: http://clinicaltrials. gov/ct2/show/NCT00820950. Accessed December 6, 2011.

153. ClinicalTrials.gov. Study of INCB018424 sustained release formulation in myelofibrosis patients. Available at: http://clinicaltrials. gov/ct2/show/NCT01340651. Accessed December 6, 2011.

154. ClinicalTrials.gov. Study of INCB018424 for acute leukemia. Available at: http://clinicaltrials.gov/ct2/show/NCT01251965. Accessed December 6, 2011.

155. ClinicalTrials.gov. Study to determine the safety and efficacy of ruxolitinib (INCB018424) in patients with polycythemia vera or essential thrombocythemia. Available at: http://clinicaltrials.gov/ct2/ show/NCT00726232. Accessed December 6, 2011.
Psoriasis: Targets and Therapy

\section{Publish your work in this journal}

Psoriasis: Targets and Therapy is international, peer-reviewed, open access journal focusing on psoriasis, nail psoriasis, psoriatic arthritis and related conditions, identification of therapeutic targets and the optimal use of integrated treatment interventions to achieve improved outcomes

\section{Dovepress}

and quality of life. Visit http://www.dovepress.com/testimonials.php to read real quotes from published authors. 